\title{
STRUCTURED SYSTEMS OF FACTORS AND EXPERIMENTAL- STATISTICAL MODELS IN STUDIES OF BUILDING COMPOSITES
}

\author{
T. Lyashenko ${ }^{1}$ \\ ${ }^{1}$ Odessa State Academy of Civil Engineering and Architecture
}

\begin{abstract}
The introduction to the article presents the objects of research, for which the proposed approach to modelling and the types of the models are intended. These are high quality composite building materials, the multicomponent dispersed systems, with the components that could be multicomponent themselves. The need to use for their design the mathematical models of the dependences of structure parameters and properties of the material on the factors of composition and processes of production and operation is noted.

Then the background of experimental-statistical (ES) models application in research and development of composite materials is considered. What they are needed for is emphasized. The peculiarities of these models are noted in contrast to the models of other classes, including the usual regression ones. The necessity of experiment design to build ES-models is also emphasized. Special types of ES-models are named, for the cases when it is necessary to consider linearly related factors ("mixtures"). The expediency of structurizing the system of all the factors under consideration and the corresponding ES-models is indicated to.

The concept of a priori and a posteriori structuring of factor systems when modeling is proposed. Systems that could include subsystems of linearly related factors and subsystems of mutually independent factors separated out at the stage of a priori structuring have been called "mixtures, technologies" systems and classified by the type of factor domains. System designations are given. Special polynomial models developed for them are presented.

For the analysis of modelling results, a posteriori allocation of the factor regions and the use of tools of composition-process fields methodology are proposed. The local fields of material properties in coordinates of one or another group of the factors and their transformation under the influence of the factors of another group can be analysed, using numerical generalizing indices of the local fields and the secondary models for these indices. The path from obtaining data of designed natural experiment for building the primary ES-models to the secondary models, for generalizing indices, based on the results of computational experiment, is schematically shown.
\end{abstract}

Keywords: mixture, factor domain, simplex, design of experiment, reduced polynomial, composition-process field.

\section{СТРУКТУРОВАНІ СИСТЕМИ ФАКТОРІВ I ЕКСПЕРИМЕНТАЛЬНО-СТАТИСТИЧНІ МОДЕЛІ ПРИ ДОСЛІДЖЕННІ БУДІВЕЛЬНИХ КОМПОЗИТІВ}

\author{
Ляшенко Т. В. ${ }^{1}$ \\ ${ }^{1}$ Одеська державна академія будівництва та архітектури
}

Анотація: У вступі до статті представлені об'єкти досліджень, для яких призначені пропоновані підхід до моделювання та види моделей. Об'єкти - високоякісні композиційні будівельні матеріали. Це багатокомпонентні дисперсні системи, 3 вкладеною многокомпонентностью. Наголошується на необхідності використовувати для їх проектування математичні моделі зв'язків параметрів структури і властивостей матеріалу з факторами рецептури і процесів виробництва і експлуатації. 
Далі розглядаються передумови застосування експериментально-статистичних (ЕС) моделей в дослідженнях і при розробці композиційних матеріалів. Підкреслюється їх призначення. Відзначаються особливості цих моделей на відміну від моделей інших класів, в тому числі від звичайних регресійних. Підкреслюється також необхідність планування експерименту для їх побудови. Називаються спеціальні типи ЕС-моделей, якщо є необхідність розглядати лінійно пов'язані фактори, «суміші». Вказується на корисність структурування системи всіх досліджуваних факторів і відповідних ЕС-моделей.

Пропонується концепція апріорного і апостеріорного структурування систем факторів при моделюванні. Системи, які могли б включати підсистеми лінійно пов'язаних факторів i підсистеми взаємонезалежних факторів, які виділяються на етапі апріорного структурування, названі системами «суміші, технології» і класифіковані за типом факторних областей. Даються позначення систем. Наводяться розроблені для них спеціальні поліноміальні моделі.

Для аналізу результатів моделювання предлагается апостеріорне виділення факторних областей і використання інструментів методології рецептурно-технологічних полів. Можуть бути проаналізовані локальні поля властивостей матеріалу в координатах тієї чи іншої групи факторів і їх трансформація під впливом факторів іншої групи, з використанням числових узагальнюючих показників локальних полів i вторинних моделей, для цих показників. Схематично показаний шлях від отримання даних спланованого натурного експерименту, для побудови первинних моделей, до побудованим за результатами обчислювального експерименту вторинним моделям, для узагальнюючих показників.

Ключові слова: суміш, факторна область, симплекс, планування експерименту, приведений поліном, рецептурно-технологічне поле. 


\section{INTRODUCTION}

The most studies in modern materials science aim at creating high grade materials that best serve exactly what they are designed for. In this sense, probably, they are called High Performance Materials [1-3]. They can provide high strength, weight reduction, cleanliness for high purity applications, high-temperature capability, materials processing efficiency, corrosion resistance, multi-functionality, long or short life and good utilization, reliability, durability, saving resources, and so on. This material might be high-strength concrete for bridge structures, but also a low-strength fast-setting mortar for short-term mine rock anchorage. The high performance materials and composite materials as their special class have been included into the list of the top 20 engineering achievements of the 20th century [4].

To create building composites that serve their purposes in the fullest measure more and more multi-component components are used (binder systems, complex admixtures, polyfractional fillers, hybrid fibres, etc.). The "nested" multicomponent is characteristic. This is testified by great number of books and papers, for instance, by these ones [5-7]. To provide desirable properties of such composites at various stages of their life (mix, forming structures, hardened composite, degrading material that should be utilised) one has to analyse quantitatively the relations of the properties with multi-component composition and process (CP) parameters (including operational conditions).

The CP-parameters, the levels of which can be set, present the vector of CP-factors, $\boldsymbol{x}=\left(x_{1}, \ldots, x_{k}\right)$. Criteria of material behavior $(Y$, generally called properties $)$ are technological and structural characteristics, functional properties, other quality criteria, and any other responses (including resources and costs) to variations of controllable inputs $x$. The levels of criteria $Y$, which characterise the material structure response to controllable effects of $\boldsymbol{x}$, provide the information for forming desirable structures through certain values of $\mathrm{CP}$-factors. And, of course, to determine these values one needs mathematical models of the relations between factors $\mathrm{x}$ and criteria $Y$, in order to analyse these relations and to "lay the quality" in design of the material (composition and modes, which would provide specified or improved levels of the properties).

\section{ANALYSIS OF LITERATURE DATA AND TARGET SETTING}

The typology of mathematical models in building materials science, by their origin $[8,9]$, comprises mathematical physics equations (important as a priori knowledge at any modelling), conceptual models, virtual models (simulations of materials structures and artificial neural networks), and experimental-statistical (ES) models. The coefficients (constants) in fundamental equations and in analytical expressions of the concepts are related to the fixed composition and modes, not to dependencies on them. The models simulating structures, in particular those that emerge with hydration [10-12], alone do not allow the levels of operational properties to be predicted, of the composite that should be designed [13, 14]. To do this, in particular, to calculate the diffusivity [15] or strength [10], the conceptual or regression models are invoked.

ES-models are widely used when studying and developing building composites, evidently since they are the ones that can connect directly the properties (not only structural and operational characteristics, but coefficients of fundamental and conceptual equations and the estimates got on simulated structures as well) with multicomponent composition and processes parameters.

The term "Experimental-Statistical Modelling" (ESM) has been put forward by V. A. Voznesensky [16, p. 32]. The development of ESM, even before the appearance of this 
term, and of its content definition [8, 16, 17], were aimed at overcoming the blackness of the "black box" [18, 19] (the origin of ESM from which can be traced back). With ESM, the black box is already lighter and more transparent. The models are no longer black box models, but, say, of gray one. ES-models are assumed to be built on the base of the best possible information, namely, on a priori knowledge and on results of the designed reasonable experiment. The statement of the problem (the purposes and possibilities) should be defined on the base of system approach and of a priori physical-chemical, technological, and other knowledge, at "pre-design of experiment" stage. Defined should be: the components of material, the intervals of their dosages and the ranges of processes parameters to be varied in the experiment (the factor region $\Omega_{\mathrm{x}}$ ), hypothetical kinds of the models $Y(\boldsymbol{x})$ to be obtained (taking into account a priori information on effects of CP-factors), other conditions. And then the ES-models, mathematical descriptions of the relationships between factors $x$ and criteria $Y$, as a rule, in the form of polynomials, are built (with least squares method followed by statistical analysis), on results of carried out designed experiment.

Design of experiment (DOE) is not only a formalized way to maximize the amount of information received with limited resources, which allows one to characterize both the individual and joint influence of the CP-factors $\boldsymbol{x}$ on the responses $Y$, with the highest possible accuracy. This is the philosophy and logic of research [20], the core of the experiment strategy $[16,21]$.

The equation (1) presents the general form of ES-model (linear in parameters, non-linear in factors).

$$
Y(\boldsymbol{x})=\sum_{l=1}^{L} b_{l} f_{l}(\boldsymbol{x})
$$

where $f_{l}(\boldsymbol{x})$ are linearly independent, basis functions (as a rule, degrees of $x$ ); in particular, the most often used are the $2^{\text {nd }}$ order polynomials (2).

$$
Y(\boldsymbol{x})=b_{0}+\sum_{i} b_{i} x_{i}+\sum_{i} b_{i i} x_{i}^{2}+\sum_{i<j} b_{i j} x_{i} x_{j}
$$

These are not just regression models (sometimes referred to as ES-models, thus discrediting the latter). The use of the dimensionless variables (most often normalised to $-1 \leq x_{\mathrm{i}} \leq+1$, instead of dimensional $\left.X_{\mathrm{i}}, X_{\mathrm{i} \text {.min }} \leq X_{\mathrm{i}} \leq X_{\mathrm{i}, \max }\right)$ gives clear physical sense to coefficients of ES-model, having dimension of the criterion $Y$ they evaluate, and ensures acceptable calculation errors.

When studying multicomponent disperse systems, the building composites among them, the system of factors under study or some of them (factor subsystem) can present the "mixture". This is when as the factors the portions (from 0 to 1 ) of the components forming the mixture (1 in a sum) should be considered. It can be the mixture of fractions of the grains of several size or different minerals, or the portions of the components in complex chemical admixtures, etc.

In these cases of linearly related factors the special kinds of polynomials and corresponding experiment designs are used [22-26]. The $1^{\text {st }}$ such models and designs were proposed by H. Sheffe: simplex-lattice design and reduced polynomial [22], simplex-centroid design and the products of designs in case of both linearly related and independent factors [23]. The reduced polynomials for the last case were given in works [25, 27, 28] (with algorithm of the synthesis of the designs in [27]). Put forward were also the reduced polynomials for the systems with two mixtures [28] (the application of this model and synthesised design were presented in [16]) and for the systems with two mixtures and mutually independent factors (presented and applied in [8]). 
Nowadays ESM is the developed methodology of researches [8, 9, 17]. Some of its elements intersect with those of the "response surface methodology" [29, 30]. But for ESM, it is important not only and not so much to build good models. ES modelling is aimed at extracting as much information as possible from the models, in which data of the experiments (of both natural or computational) are convoluted. For ESM, it is not so much the models as such that are important, but the tasks that can be solved with their help, including in tandem with fundamental and structural-simulation models.

Of course, the polynomial form does not contribute to explanation of mechanisms of the material behavior, to conclusions and projections of a general nature. The "richness of reality" hidden in ES-models and the knowledge that they can potentially contain may be lost.

Decomposition of factors system (the allocation of subsystems in accordance with factor nature, character, and the degree of influence on the properties) and the use of the corresponding structured ES-models could reduce the losses, could help to extract from the models, more fully, the information that is folded in them. Allocating the influence of factor subsystems and their synergism could mitigate to some extend the contradiction between the "simplicity" of the integral polynomial model and the structural complexity of the object (composite material).

\section{PURPOSE AND OBJECTIVES OF RESEARCH}

The purpose of this article is to generalize and to promote the "structuring approach" to solving the tasks of building materials science with the help of ES-models.

The generalization implies some classification of the systems under consideration and of ES-models that would describe them. The "structuring" suggests this, firstly, at the stage of formulating the tasks to be solved (a priory, before the experiment, before building the models on experiment results). Secondly, at the stage of solving the tasks (a posteriori, after the experiment, using the models already obtained on its results).

\section{RESULTS}

A priori structuring. Decomposition of factors system should begin with meaningful (technological) statement of the problem of research and development of composite material. CP-factors are divided into subsystems, first of all, in accordance with the nature and degree of their influence on the structure and the properties of the material. These can be: a group of factors that define the properties of the matrix (water-binder ratio, concentration of additives, etc.); factors that set the amount of filler and its dispersion and (or) mineral composition; the composition of the complex admixture; process modes (temperature at different stages of the process, pressure in autoclave, etc.); operational factors that condition the aggressiveness of the environment; a set of factors from different such groups, to variation of which (according a priori data) the responses $Y$ are most or least sensitive; and so on.

When passing to mathematical descriptions, corresponded to factor subsystems identified at the stage of the technological statement of the problem can be different types of the domains in the factor space. According to these types of factor domains the factor systems and their constituent subsystems have been named and designated.

"Technology", $\boldsymbol{T}$, is the system (subsystem) of mutually independent factors.

$T_{\mathrm{p}}$ includes $p$ factors. The domain of factor space corresponding to $T_{\mathrm{p}}$ is $p$-dimensional cube (line segment, square, cube...) of mutually independent normalized factors $x_{\mathrm{i}},-1 \leq x_{\mathrm{i}} \leq+1, \boldsymbol{x}=\left(x_{1}, x_{2}, \ldots, x_{\mathrm{i}}, \ldots, x_{\mathrm{p}}\right) \in \Omega_{\mathrm{x}}$.

These can be both formulation factors (for example, dosage of additive relative to the content of the base component) and parameters of production and operation processes. 


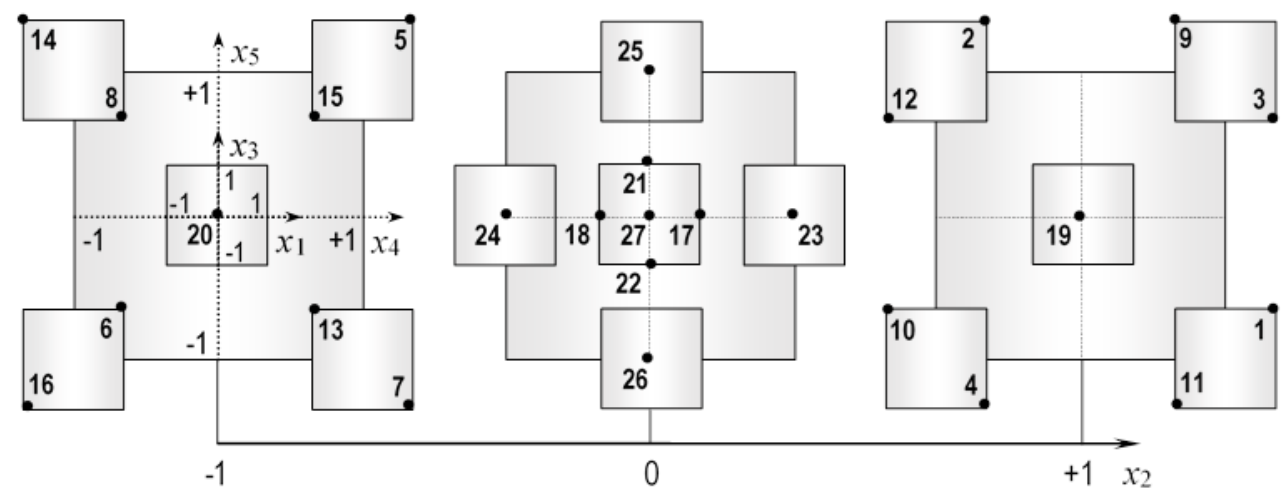

Fig. 1. The display of the $2^{\text {nd }}$ order 5 factors design of experiment in system $T_{1} T_{2} T_{2}$ factor region

Several subsystems "technology" can be separated in $T_{\mathrm{p}}$ (specifically, $T_{\mathrm{p} 1}$ and $T_{\mathrm{p} 2}$, $p_{1}+p_{2}=p$, then it is, $\left.T_{\mathrm{p} 1} T_{\mathrm{p} 2}\right)$. Structured image of such factor system can be used, in particular, just to show the points of experiment design (Fig. 1).

"Mixture", $\boldsymbol{M}$, is the system (subsystem) of linearly related factors $v_{\mathrm{i}}$, the portions of the components forming the mixture, $0 \leq v_{\mathrm{i}} \leq 1, \sum v_{\mathrm{i}}=1, \boldsymbol{v}=\left(v_{1}, v_{2}, \ldots, v_{\mathrm{i}}, \ldots, v_{\mathrm{q}}\right) \in \Omega_{\mathrm{v}} . M_{\mathrm{q}}$ is the mixture of $q$ components. The domain $\Omega_{v}$ of factor space is $(q-1)$-dimensional simplex (segment, triangle, tetrahedron ...). There might be more than one mixture in the system, as mentioned above ( $w$ is used as the second designation). In particular, this could be $M_{\mathrm{qv}} M_{\mathrm{qw}}$.

In some cases [26], especially when the factor domain is a limited part of the simplex, it may be advisable to use, instead of $v$ or $w$, the mutually independent variables $x$ (specifically, the dosages of the components relative to the one that is necessarily present in the mixture, i.e., $T$-factors).

Factor domains and subdomains can be parts of cubes and of simplices cut out by additional constraints on $\boldsymbol{v}, \boldsymbol{w}$, and $\boldsymbol{x}$ (for example, shown in [17]), as well as prisms and other products of the whole and bounded cubes and simplices.

The features of the factor space in problems of materials development may lead to consideration of the systems "mixtures, technologies - properties", for which the generalized designation $M s T s Q$ can be used, where $Q$ denotes the quality, defined by a set of material properties (of criteria $Y$ ).

The system of factors "mixtures, technologies" (MsTs) generalizes practically all combinations (considered in building materials science) of linearly related and mutually independent variables, which could be included in ES-model.

In most specific studies of building composite materials, it is not reasonable to include in consideration more than 7 factors, more than 2 "mixtures", and more than two $T$-subsystems when designing certain experiment and meaning subsequent analysis of its results (in some cases it could be 8 [31] and 9 [32] factors and more than 2 technological subsystems).

The vector of the factors in $M_{\mathrm{qv}} M_{\mathrm{qw}} T_{\mathrm{p} 1} T_{\mathrm{p} 2} Q$ can be written as $z=\left(\boldsymbol{v}, \boldsymbol{w},\left(\boldsymbol{x}_{1}, \boldsymbol{x}_{2}\right)\right) \in \Omega_{\mathrm{z}}$. The structured factor region $\Omega_{\mathrm{z}}$ may be written as the Cartesian product of the corresponding subregions, $\Omega_{\mathrm{z}}=\Omega_{\mathrm{v}} \otimes \Omega_{\mathrm{w}} \otimes\left(\Omega_{\mathrm{x} 1} \otimes \Omega_{\mathrm{x} 2}\right)$. In particular, for $z=\left(v_{1}, v_{2}, v_{3}, x_{1}, x_{2}\right)$ the region $\Omega_{\mathrm{z}}$ is a set of points of the mixture triangle at each point of the square of mutually independent factors (and vice versa).

Given in Tables 1 and 2 are the designations for a number of typical factor systems "mixtures, technologies" and variants of displaying the corresponding factor regions ("inverse" mappings are meant too, in particular, "squares on triangle" in addition to "triangles on square"). 
Corresponded to structured systems of the factors are the structured forms of ES-models. Given below are the types of ES-models for "Mixtures, Technologies - Properties" systems. For a number of representatives of those systems the models written in structured form are shown, not the long trains of polynomial terms, but the blocks of them related to certain factor subsystems and synergetic effects.

Table 1

Designations of factor systems with variants of displaying the domains of 2-4 factors.

\begin{tabular}{|c|c|c|c|c|}
\hline \multirow{2}{*}{ Factors system } & \multirow{2}{*}{ 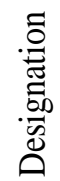 } & \multicolumn{3}{|c|}{ Number of factors $k=\left(p=p_{1}+p_{2}\right)+q_{\mathrm{v}}+q_{\mathrm{w}}$} \\
\hline & & 2 & 3 & 4 \\
\hline «Mixture» & $\Sigma$ & $\begin{array}{c}M_{2} \\
\text { Segment (- ) }\end{array}$ & $\begin{array}{c}M_{3} \\
\text { Triangle }(\Delta)\end{array}$ & $\begin{array}{c}M_{4} \\
\text { Tetrahedron }\end{array}$ \\
\hline «Technology» & F & $T_{2}$ Square $(\square)$ & $T_{3}$ Cube & \\
\hline $\begin{array}{l}\text { «Mixture, } \\
\text { Mixture» }\end{array}$ & $\sum_{\sum}^{5}$ & & & $\begin{array}{c}M_{2} M_{2} \\
\text { «- on - » }\end{array}$ \\
\hline $\begin{array}{c}\text { «Mixture, } \\
\text { Technology» }\end{array}$ & $\sum$ & & $\begin{array}{c}M_{2} T_{1} \\
«-\text { on - » }\end{array}$ & $\begin{array}{c}M_{3} T_{1} \\
\ll \Delta \text { on }-» \\
\text { (triangular prism) }\end{array}$ \\
\hline $\begin{array}{l}\text { «Technology, } \\
\text { Technology» }\end{array}$ & $\stackrel{2}{2}$ & $\begin{array}{c}T_{1} T_{1} \\
\text { «- on - » }\end{array}$ & $\begin{array}{c}T_{2} T_{1} \\
\ll \square \text { on }-»\end{array}$ & $\begin{array}{c}T_{2} T_{2}, \quad 《 \square \text { on } \square » \\
\text { «Cubes on - }\end{array}$ \\
\hline $\begin{array}{l}\text { «Mixture, } \\
\text { Technology, } \\
\text { Technology» }\end{array}$ & $e^{\stackrel{2}{2}}$ & & & $\begin{array}{c}M_{2} T_{1} T_{1} \\
\text { «rectangles } \\
\text { and } \square \text { on - » }\end{array}$ \\
\hline
\end{tabular}

For $\boldsymbol{T}_{\mathrm{p} 1} \boldsymbol{T}_{\mathrm{p} 2} \boldsymbol{Q}$ systems these are the ordinary polynomial $P(\boldsymbol{x})$ written in blocks corresponding to individual subsystems and their synergies, like the one of the $2^{\text {nd }}$ order (3), for $T_{2} T_{2}$.

$$
\begin{array}{c|ll|}
Y(\boldsymbol{x})=b_{0} & \begin{array}{ll}
+b_{1} x_{1}+b_{11} x_{1}{ }^{2}+b_{12} x_{1} x_{2} \\
+b_{2} x_{2}+b_{22} x_{2}^{2}
\end{array} \\
\hline \begin{array}{ll}
+b_{3} x_{3}+b_{33} x_{3}{ }^{2}+b_{12} x_{1} x_{2} \\
+b_{4} x_{4}+b_{44} x_{4}^{2}
\end{array} & \begin{array}{l}
+b_{13} x_{1} x_{3} \\
+b_{14} x_{1} x_{4} \\
+b_{23} x_{2} x_{3} \\
+b_{24} x_{2} x_{4}
\end{array} \\
\hline
\end{array}
$$

The free term $b_{0}$ presents the level of $Y$ at medium values of all $x$, equal to zero, at the center of the experiment. Block (a) evaluates the effects of one group of factors (let it be matrix factors, dosages of admixtures) at central values of the factors from another group (quantity and specific surface of filler, for instance). The effects of those from another group at central values of the $1^{\text {st }}$ group factors are presented in block (b). Block (c) evaluates the synergism (antagonism) of the factors from different groups. 
To describe the systems $\boldsymbol{M}_{\mathrm{q}} \boldsymbol{T}_{\mathrm{p}} \boldsymbol{Q}$, with factor region $\Omega_{\mathrm{v}} \otimes \Omega_{\mathrm{x}}$ (simplices on cube and vice versa), the reduced polynomials, $P_{\mathrm{r}}(\boldsymbol{v}, \boldsymbol{x})$, can be used. Incomplete $3^{\text {rd }}$ degree polynomial (4) and polynomial of the $3^{\text {rd }}$ degree (5) are shown below (the higher degree would not be reasonable). The usual polynomial of $k=q+p$ variables is reduced to this form by substituting equalities in it following from the linear relation of $q$ factors. The model (5) contains $C_{q+p+2}^{3}$ terms and coefficients. The terms in its $1^{\text {st }}$ line present Sheffe reduced polynomials (of the $1^{\text {st }}$, then of the $2^{\text {nd }}$ order, incomplete of $3^{\text {rd }}$ degree, and of $3^{\text {rd }}$ degree).

Table 2

\begin{tabular}{|c|c|c|c|c|}
\hline \multirow{2}{*}{ Factors system } & \multirow{2}{*}{ 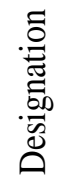 } & \multicolumn{3}{|c|}{ Number of factors $k=\left(p=p_{1}+p_{2}\right)+q_{\mathrm{v}}+q_{\mathrm{w}}$} \\
\hline & & 5 & 6 & 7 \\
\hline «Mixture, Mixture» & $\sum_{\substack{z \\
z}}^{3}$ & $\begin{array}{c}M_{3} M_{2} \\
« \Delta \text { on - » }\end{array}$ & $\begin{array}{c}M_{3} M_{3} \\
« \Delta \text { on } \Delta »\end{array}$ & $\begin{array}{c}M_{4} M_{3} \\
\text { «Tetrahedrons } \\
\text { on } \Delta »\end{array}$ \\
\hline $\begin{array}{c}\text { «Mixture, } \\
\text { Technology» }\end{array}$ & 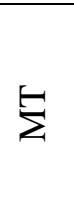 & $\begin{array}{c}M_{4} T_{1} \\
\text { «Tetrahedrons on } \\
-» \\
M_{3} T_{2}, \ll \Delta \text { on } \square »\end{array}$ & 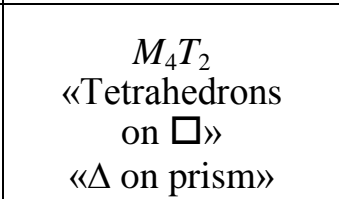 & $\begin{array}{c}M_{4} T_{3} \\
\text { «Tetrahedrons } \\
\text { on cube» }\end{array}$ \\
\hline $\begin{array}{l}\text { «Technology, } \\
\text { Technology» }\end{array}$ & $\frac{2}{2}$ & $\begin{array}{c}T_{3} T_{2} \\
\text { «Cubes on } \square »\end{array}$ & $\begin{array}{c}T_{2} T_{1} \\
« \square \text { on }-»\end{array}$ & $\begin{array}{c}T_{2} T_{2}, \quad « \square \text { on } \square » \\
\text { «Cubes on }-»\end{array}$ \\
\hline $\begin{array}{c}\text { «Mixture, } \\
\text { Mixture, } \\
\text { Technology» }\end{array}$ & 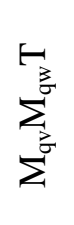 & $\begin{array}{c}M_{2} M_{2} T_{1} \\
\ll \square \text { and } \\
\text { rectangles on - } ~\end{array}$ & 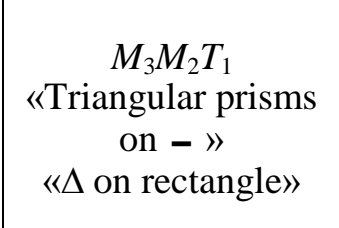 & $\begin{array}{c}M_{3} M_{3} T_{1} \\
\text { «Triangular prisms on } \Delta » \\
M_{3} M_{2} T_{2} \\
\text { «Triangular prisms on } \square \text { } \\
\text { « } \Delta \text { on prisms» }\end{array}$ \\
\hline $\begin{array}{l}\text { «Mixture, } \\
\text { Technology, } \\
\text { Technology» }\end{array}$ & $\overbrace{}^{\frac{2}{2}}$ & $\begin{array}{c}M_{3} T_{1} T_{1} \\
\text { «triangular prisms on } \\
-», \ll \Delta \text { on } \square »\end{array}$ & 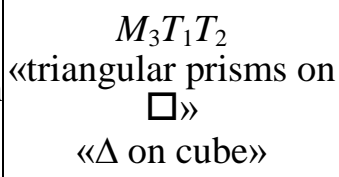 & $\begin{array}{c}M_{3} T_{2} T_{2}, M_{4} T_{1} T_{2} \\
\ll \Delta \text { and tetrahedrons on } \square, \\
-, \text { cube» }\end{array}$ \\
\hline \multicolumn{5}{|c|}{$Y(\boldsymbol{v}, \boldsymbol{x})=\sum_{i=1}^{q} A_{i} v_{i}+\sum_{j>i=1}^{q} A_{i j} v_{i} v_{j}+\sum_{i<j<l} A_{i j l} v_{i} v_{j} v_{l}+\sum_{j=1}^{p} \sum_{i=1}^{q} D_{i j} v_{i} x_{j}+\sum_{1 \leq i<j \leq p} b$} \\
\hline \multicolumn{5}{|c|}{ 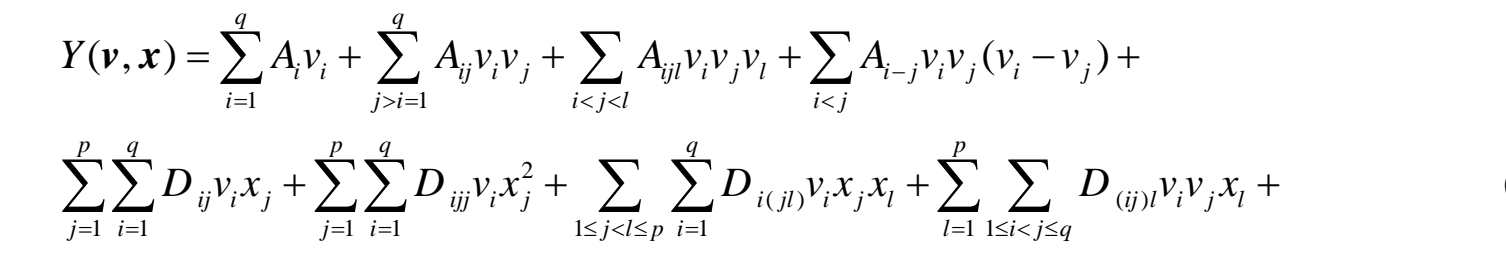 } \\
\hline
\end{tabular}

Coefficients $A$ correspond to those in Sheffe polynomial, describing the system $M Q$ at $\boldsymbol{x}=0 . A_{\mathrm{i}}$ defines the level of $Y$ at the center of $\Omega_{\mathrm{x}}$ when only $i$-th component is in the mixture. 
Other $A$ characterize the nonlinearity of the property changing with mixing the components. Coefficients $D$ and $b$ define the variation of $A$ with $\boldsymbol{x}$ varying. form.

The equation (6) presents the $2^{\text {nd }}$ order model for the system $M_{3} T_{1} Q$ written in structured

$$
\begin{aligned}
& Y\left(v_{1}, v_{2}, v_{3}, x\right) \begin{array}{ll}
=A_{1} v_{1}+A_{12} v_{1} v_{2}+A_{13} v_{1} v_{3} \\
+A_{2} v_{2} \\
+A_{3} v_{3}
\end{array} \\
&+A_{23} v_{2} v_{3} \\
&+b_{11} x^{2}
\end{aligned} \begin{aligned}
& \begin{array}{l}
+D_{1} v_{1} x \\
+D_{2} v_{2} x \\
+D_{3} v_{3} x
\end{array} \\
& \hline
\end{aligned}
$$

The analysis of a priori data may not allow to put forward a hypothesis about the relation between $Y$ and $\boldsymbol{z}=(\boldsymbol{v}, \boldsymbol{x})$ corresponding to the reduced polynomial, for example, about the absence of the effects $v_{\mathrm{i}} v_{\mathrm{j}} x$, as in (6). Then one can use as ES models the products of ordinary and reduced polynomials for individual subsystems, if it would be possible to carry out a costly experiment to estimate a large number of coefficients and high-order effects (many of which may turn out to be insignificant).

In models-products, each of the model coefficients for one of the subsystems can be written as a function of the factors of the other subsystem. In particular, $Y(\boldsymbol{v}, \boldsymbol{x})$ can be expressed by the product (7) of the reduced Sheffe polynomial and an ordinary polynomial, where $i$ and $j$ are the indices of effects, of the basis functions $f$, in models-multipliers.

$$
Y(\boldsymbol{v}, \boldsymbol{x})=P_{\mathrm{r}}(\boldsymbol{v}) \times P(\boldsymbol{x})=\sum\left\{A_{\mathrm{j}}=\left[\sum b_{\mathrm{ij}} \cdot f_{\mathrm{i}}(\boldsymbol{x})\right]\right\} \cdot f_{\mathrm{j}}(\boldsymbol{v}) .
$$

In particular, the product of second-order polynomials (Scheffe and usual) for the $M_{3} T_{1} Q$ system can be written in the form (8) or (9).

$$
\begin{aligned}
Y\left(v_{1}, v_{2}, v_{3}, x\right)= & \left(b_{0.1}+b_{1.1} x+b_{11.1} x^{2}\right) \cdot v_{1} \\
+ & \left(b_{0.2}+b_{1.2} x+b_{11.2} x^{2}\right) \cdot v_{2} \\
& +\left(b_{0.3}+b_{1.3} x+b_{11.3} x^{2}\right) \cdot v_{3} \\
& +\ldots \\
+ & \left(b_{0.23}+b_{1.23} x+b_{11.23} x^{2}\right) \\
Y\left(v_{1}, v_{2}, v_{3}, x\right)= & \left(A_{1.0} v_{1}+A_{2.0} v_{2}+A_{3.0} v_{3}+A_{12.0} v_{1} v_{2}+A_{13.0} v_{1} v_{3}+A_{23.0} v_{2} v_{3}\right) \\
& +\left(A_{1.1} v_{1}+A_{2.1} v_{2}+A_{3.1} v_{3}+A_{12.1} v_{1} v_{2}+A_{13.1} v_{1} v_{3}+A_{23.1} v_{2} v_{3}\right) \cdot x \\
& +\left(A_{1.11} v_{1}+A_{2.11} v_{2}+A_{3.11} v_{3}+A_{12.11} v_{1} v_{2}+A_{13.11} v_{1} v_{3}+A_{23.11} v_{2} v_{3}\right) \cdot x^{2} .
\end{aligned}
$$

To evaluate all 18 coefficients of the model $(8,9)$, at least 18 trials (in points of experiment design) are required. The model (6) needs minimum 10 trials to estimate its coefficients, but is unable to evaluate the relation of synergy within the mixture with the level of "technological" factor.

The reduced polynomials $P_{\mathrm{r}}(\boldsymbol{v}, \boldsymbol{w})$, for the system $\boldsymbol{M}_{\mathrm{qv}} \boldsymbol{M}_{\mathrm{qw}} \boldsymbol{Q}$ (and factor regions $\Omega_{\mathrm{v}} \otimes \Omega_{\mathrm{w}}$ ), the functions of two groups of linearly dependent variables, have been also put forward. The models of the $2^{\text {nd }}$ and $3^{\text {rd }}$ order have the form (10) and (11) respectively and contain $C_{q v+q w+n-2}^{n}$ coefficients ( $n$ is the order of polynomial).

$$
Y(\boldsymbol{v}, \boldsymbol{w})=\sum_{1 \leq i<j \leq q v} A_{i j} v_{i} v_{j}+\sum_{1 \leq i<j \leq q w} B_{i j} w_{i} w_{j}+\sum_{i=1}^{q v} \sum_{j=1}^{q w} C_{i j} v_{i} w_{j},
$$




$$
\begin{aligned}
Y(\boldsymbol{v}, \boldsymbol{w}) & =\sum_{1 \leq i<j<l \leq q v} A_{i j l} v_{i} v_{j} v_{l}+\sum_{1 \leq i<j \leq q v} A_{i-j} v_{i} v_{j}\left(v_{i}-v_{j}\right) \\
& +\sum_{1 \leq i<j<l \leq q w} B_{i j} w_{i} w_{j} w_{l}+\sum_{1 \leq i<j \leq q w} B_{i-j} w_{i} w_{j}\left(w_{i}-w_{j}\right) \\
& +\sum_{i=1}^{q v} \sum_{j=1}^{q w} C_{i j} v_{i} w_{j}+\sum_{1 \leq i<j \leq q v} \sum_{l=1}^{q w} C_{(i j) l} v_{i} v_{j} w_{l}+\sum_{l=1}^{q v} \sum_{1 \leq j<l \leq q w} C_{i(j l)} v_{i} w_{j} w_{l} .
\end{aligned}
$$

One needs sufficiently less experiment trials to build such models than to estimate the coefficients of the product of two Sheffe polynomials. In particular, if $q_{\mathrm{v}}=q_{\mathrm{w}}=3$ the production of two $2^{\text {nd }}$ degree multipliers contains 36 terms, while reduced polynomial (12) only 15 , providing the decrease in resource consumption by 2.4 times, with saturated design of the experiment.

$$
\begin{aligned}
Y\left(v_{1}, v_{2}, v_{3}, w_{1}, w_{2}, w_{3}\right)= & A_{12} v_{1} v_{2}+A_{13} v_{1} v_{3}+A_{23} v_{2} v_{3} \\
& +B_{12} w_{1} w_{2}+B_{13} w_{1} w_{3}+B_{23} w_{2} w_{3} \\
& +C_{11} v_{1} w_{1}+C_{12} v_{1} w_{2}+C_{13} v_{1} w_{3} \\
& +C_{21} v_{2} w_{1}+C_{22} v_{2} w_{2}+C_{23} v_{2} w_{3} \\
& +C_{31} v_{3} w_{1}+C_{32} v_{3} w_{2}+C_{13} v_{3} w_{3} .
\end{aligned}
$$

The coefficients $A$ and $B$ in (10-12) characterize the nonlinearity in changing material property when mixing the components independently in two mixtures. Coefficients $C_{\mathrm{ij}}$ correspond to the levels of $Y$ when present in the $1^{\text {st }}$ mixture is only the $i$-th component and only the $j$-th is in the $2^{\text {nd }}$ mixture. $C_{\mathrm{ijl}}$ in (11) account for nonlinearity of mixing the components in one of the mixtures for the "pure" components in another. For instance, such parameter might evaluate the effect of mixing "short" and "long" fibres when only high specific surface component is in the filler.

The reduced incomplete $3^{\text {rd }}$ degree polynomials $(12,13)$ have been obtained for the systems "mixtures, technologies - properties", $\boldsymbol{M}_{\mathrm{qv}} \boldsymbol{M}_{\mathrm{qw}} \boldsymbol{T}_{\mathrm{p}} \boldsymbol{Q}$ (with factor regions $\left.\Omega_{\mathrm{v}} \otimes \Omega_{\mathrm{w}} \otimes \Omega_{\mathrm{X}}\right)$.

$$
\begin{aligned}
& Y(\boldsymbol{v}, \boldsymbol{w}, \boldsymbol{x})=\sum_{j>i=1}^{q v} A_{i j} v_{i} v_{j}+\sum_{j>i=1}^{q w} B_{i j} w_{i} w_{j}+\sum_{i=1}^{q v} \sum_{j=1}^{q w}\left(C_{i j}+\sum_{l=1}^{p} R_{i j l} x_{l}\right) v_{i} w_{j}+\sum_{i=1}^{p} b_{i i} x_{i}^{2}+\sum_{j>i=1}^{p} b_{i j} x_{i} x_{j}, \\
& Y(\boldsymbol{v}, \boldsymbol{w}, \boldsymbol{x})=Y_{(13)}+\sum_{l=1}^{p}\left(\sum_{j>i=1}^{q v} P_{i j l} v_{i} v_{j}+\sum_{j>i=1}^{q w} Q_{i j l} w_{i} w_{j}\right) x_{l}
\end{aligned}
$$

Coefficients $R, P, Q$ reflect a linear change in the corresponding parameters of $M M Q$ models in dependence on $\boldsymbol{x}$. When substituting the fixed values of certain factors in the models for $M_{\mathrm{qv}} M_{\mathrm{qw}} T_{\mathrm{p}} Q$, specifically in (14), all the types of models considered above are obtained, describing the systems that are simpler in structure and dimension.

A posteriori structuring helps to extract the information and the knowledge folded (hidden) in the ES-models obtained. Aimed at the same is the methodology of properties fields (of $Y$ criteria) in coordinates of composition and processes parameters [9, 33], described by ES-models. The concepts and tools of composition-process fields methodology (the means of computational materials science) are helpful in realization of structuring approach.

In accordance with the ideology of DOE, all components of the vector $z$ are included in ES-model. Such model describes the whole field $Y(z)$, in the domain $\Omega_{\mathrm{z}}$, of all the factors under consideration. The structured model of the whole field $Y\left(z=\left(z_{\mathrm{gr}}, z_{\mathrm{ch}}\right)\right)$ represents also the variety of the local fields $Y\left(z_{\mathrm{gr}} / z_{\mathrm{ch}}\right)$, in the coordinates of a particular group of gradient factors, forming the local fields $\left(z_{\mathrm{gr}} \in \Omega_{\mathrm{gr}}\right.$, producing a gradient of $Y$ ), at certain values of a 
group of factors that could change them $\left(z_{\mathrm{ch}} \in \Omega_{\mathrm{ch}}\right)$. Any useful combination of separating out of $z$ the gradient factors and the changing factors can be considered. The transformation of $Y\left(z_{\mathrm{gr}}\right)$ under the influence of $z_{\mathrm{ch}}$ can be described.

The specific features of the whole and of the local fields are characterized (measured) by their generalizing indices $\left(G_{\mathrm{Y}}\{z\}, G_{\mathrm{Y}}\left\{z_{\mathrm{gr}}\right\}\right.$, numerical characteristics of distribution of $Y$ level over the region of $\mathrm{CP}$-factors). These could be the maximal and minimal levels of $Y$, the increments, the levels at some special points and their coordinates, etc. [9, 33], calculated (estimated) with ES-models.

By the estimates of $G_{\mathrm{Y}}\left\{z_{\mathrm{gr}}\right\}$ at fixed values of $\boldsymbol{z}_{\mathrm{ch}}$, the secondary ES-models (in relation to the primary ES-model, built on primary experimental data) can be obtained, describing the dependences of the generalizing indices of local fields on the factors $\boldsymbol{x}_{\mathrm{ch}}$ that change these fields.

The models for generalizing indices, $G_{Y}\left\{z_{\mathrm{gr}}\right\}\left(z_{\mathrm{ch}}\right)$, are built on the estimates of $G_{\mathrm{Y}}\left\{z_{\mathrm{gr}}\right\}$ calculated for the fields $Y\left(z_{\mathrm{gr}}\right)$ at points $z_{\mathrm{ch}}$ of the designed computational (secondary, simulation) experiment (in $\Omega_{\mathrm{ch}}$ region, in accordance with the form of the secondary model).

In general, the path from obtaining real data on $Y$ at $N_{1}$ points of the design of real (natural) experiment to obtaining, by the results of $N_{2}$ tests in designed computational experiment, the models that would express the features of the dependences of properties $Y$ on $\mathrm{CP}$-factors $z$, may be presented with the formal chain shown in Fig. 2.

The chain "natural experiment - secondary model" reflects the alternation of composing and decomposing (synthesis and analysis) of the description of the system under study when moving from the particular to the general. This is effective use of the "particular" when formulating a question to the nature (designed real experiment) - generalization in an attempt to get an answer (ES-model) - analysis, structuring when stating a new question (designed computational experiment), and at a higher level of knowledge - the new level of generalizing the empirical information (models for generalizing indices).

As a result, for each of the studied criteria $Y$, in addition to the whole primary ES-model, a material scientist-technologist has at his disposal a set of ES-models of a lower dimension the models of local fields and secondary models for $G_{\mathrm{Y}}$ indices. The $G_{\mathrm{Y}}\left\{z_{\mathrm{gr}}\right\}\left(z_{\mathrm{ch}}\right)$ model may be required for quantitative analysis of $Y\left(z_{\mathrm{gr}}\right)$ transformations under the influence of $z_{\mathrm{ch}}$, for controlling the local field through these factors, for its optimisation by one or another criterion $G_{\mathrm{Y}}\left\{z_{\mathrm{gr}}\right\}$.

When analysing the results of the modelling it may be useful to compare the local fields $Y\left(z_{\mathrm{gr}}\right)$ for "contrasting" $z_{\mathrm{ch}}$, with the largest difference in properties over the range of change factors. Helpful for meaningful analysis are plots and maps (isolines, surfaces) of local fields at different levels of $z_{\mathrm{ch}}$. These are already widely used diagrams "squares on a square", "squares on a triangle", etc., often with displaying on the carrying figure (in $z_{\mathrm{ch}}$ coordinates) the changes in the maximum and minimum levels of local fields, absolute and relative differences, and other generalizing indices $[9,33]$.

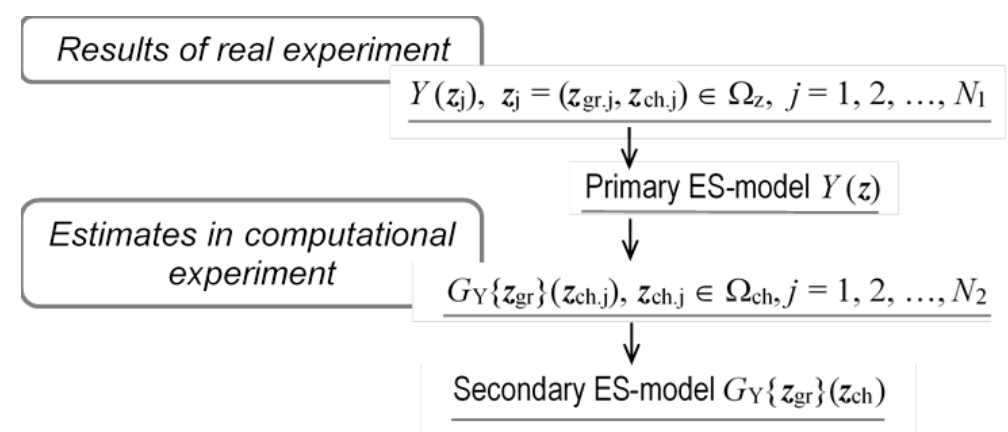

Fig. 2. The path "from experimental data to generalized descriptions" 


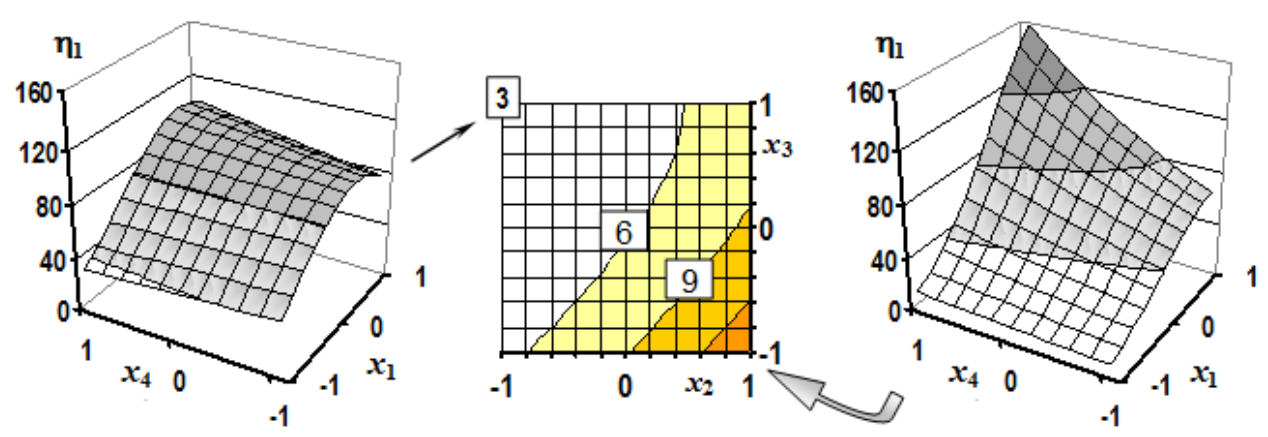

Fig. 3. Two local fields $\eta_{1}\left(x_{1}, x_{4}\right)$ and relative decrease of $\eta_{1}$ in such fields for various $M M C$ and $M C$ - on $\left\{x_{2}, x_{3}\right\}$-square

Shown in Fig. 3 are two representatives of the local fields of effective viscosity of the mortar, $\eta_{1}\left(\mathrm{~Pa} \cdot \mathrm{s}\right.$, at shear rate $\left.1 \mathrm{~s}^{-1}\right)$, in coordinates of the dosages of 2 binder components (gradient factors), at two from pairs of values of 2 change factors that were varied in computational experiment [34]. The relative decrease of viscosity due to binder components (generalizing index) in dependence on molecular mass (MMC) and the quantity of methylcellulose (MC) is shown on the square of these change factors.

\section{CONCLUSIONS}

The concept of a priory and a posterior structuring the system of factors in researches of building composite materials has been put forward. The systems, which might include the "mixtures", the subsystems of linearly related factors, have been classified by the types of factor domains. The developed kinds of polynomial models for these systems are given.

Structuring the factor systems at a posteriori stage of a study, the local fields of material properties with their generalizing indices, and the visualization possibilities help in "fighting dimensionality" when designing the multicomponent composite materials.

It seems promising to use ES-models for describing and analyzing the combined effect of design parameters and of composition of the material of a building structure (two subsystems of factors) on its properties.

\section{References}

1. Mindes, S. (2006). High performance concrete: where do we go from here? In A. M. Brandt, V. C. Li, I. H. Marshall (Eds.). Brittle Matrix Composites. 8. 15-23. Cambridge: Woodhead Publ. Ltd., Warsaw: ZTUREK RSI.

2. C. Shi and Y. L. Mo (2008). High-Performance Construction Materials. Science and Applications World Scientific. https://doi.org/10.1142/6793.

3. W. P. De Wilde, C. A. Brebbia and S. Hernández (2012). High Performance Structures and Materials VI. WITpress.

4. Constable, G., Somerville, B. (2003). A Century of Innovation: Twenty Engineering Achievements that Transformed our Lives. Washington, DC: Joseph Henry Press. https://doi.org/10.17226/10726. Caijun Shi, C., Roy, D., Krivenko, P. (2019). Alkali-Activated Cements and Concretes. CRC Press.

5. P. Samui, D. Kim, N. Iyer, S. Chaudhary (Eds.) (2020). New Materials in Civil Engineering. Butterworth-Heinemann.

6. Khan, M., Cao, M. (2021). Effect of hybrid basalt fibre length and content on properties of cementitious composites. Magazine of Concrete Research. 73 (10). 487-498. https://doi.org/10.1680/jmacr.19.00226.

7. Voznesensky, V. A., Lyashenko, T. V., Ivanov, Y. P., Nikolov, I. I. (1989). EVM i optimizaciya kompozicionnyh materialov [Computers and Optimisation of Composite Materials]. Kiev: Budivelnik. [in Russian]. 
8. Lyashenko, T. V., Voznesensky, V. A. (2017). Metodologiya recepturno-tekhnologicheskih polej v komp'yuternom stroitel'nom materialovedenii [Composition-process fields methodology in computational building materials science]. Odessa: Astroprint. [in Russian].

9. Bentz, D. P. (1999). Modelling cement microstructure: Pixels, particles, and property prediction. Materials and Structures. 32. 187-195.

10.Le, N.L.B., Stroeven, M., Sluys, L. J., Stroeven, P. (2013). A novel numerical multi-component model for simulating hydration of cement. Computational Materials Science. 78. 12-21.

11.Stroeven, P., Slowik, M. (2019). Economic and reliable estimation of cementitious material properties on the basis of virtual models. In M.A. Glinicki, D. Jóźwiak-Niedźwiedzka, C. K.Y. Leung, J. Olek (Eds.), Brittle Matrix Composites. 8. 35-44. Warsaw: Institute of Fundamental Technological Research.

12.Wittmann, F. H., Roelfstra, P. E., Sadouki, H. (1984). Simulation and Analysis of Composite Structures. Materials Science and Engineering. 68. 239-248.

13.Garboczi, E. J. (2013). The computational materials science of concrete: Past, present and future. American Ceramic Society Bulletin. 92 (4). 40-45.

14.Garboczi, E. J., Bentz, D. P. (1992). Computer simulation of the diffusivity of cement-based materials. J. of Materials Science. 27. 2083-2092.

15. Voznesensky, V. A. (Ed.). (1983). Sovremennye metody optimizacii kompozicionnyh materialov [Contemporary Methods of Optimization of Composite Materials], Kiev: Budevel'nik. [in Russian].

16.Lyashenko, T. V., Voznesensky, V. A. (1995). Experimental-statistical modeling in computational materials science. In: Proc. $3^{\text {rd }}$ Int. Applied Statistics in Industry Conf., 287-298. Dallas: ACG Press.

17.Bunge, M. (1963). A general black-box theory. Philosophy of Science. 30 (4). 346-358.

18. Ashby, W. R. (1956). The black box. In An Introduction to Cybernetics, 86-117. London: Chapman \& Hall.

19.Nalimov, V. V., Golikova, T. I. (1981). Logicheskie osnovaniya planirovaniya eksperimenta [Logical foundations of designing an experiment], $2^{\text {nd }}$ ed. Moscow: Metallurgiya. [in Russian].

20.Voznesensky, V. A. (1981). Statisticheskie metody planirovaniya eksperimenta $v$ tekhnikoekonomicheskih issledovaniyah [Statistical methods of experiment design in technical and economic studies], $2^{\text {nd }}$ ed. Moscow: Finansy i Statistika. [in Russian].

21.Sheffe, H. (1958). Experiments with mixtures. J. Roy. Statist. Soc., B. 20 (2). 344-360.

22. Sheffe, H. (1963). Simplex-centroid design for experiments with mixtures. J. Roy. Statist. Soc., B. 25(2). 235-263.

23.Zedgenidze, I. G. (1976). Planirovanie eksperimenta dlya issledovaniya mnogokomponentnyh sistem [Design of Experiments for the Study of Multi-Component Systems]. Moscow: Nauka. [in Russian].

24.Vuchkov, I. Jonchev, H. (1979). Planirane i analiz na eksperimenta pri izsledvane na svojstvata na smesi $i$ splavi [Design and analysis of the experiment in studies of the properties of mixtures and alloys]. Sofia: Tekhnika. [in Bulgarian].

25.Cornell, J. A. (2002). Experiments with Mixtures: Designs, Models, and the Analysis of Mixture Data. $3^{\text {rd }}$ ed. Wiley.

26.Danilenko, E. L, Lyashenko, T. V. (1979). Raschet tochnyh optimal'nyh planov na vypuklyh mnogogrannikah [Calculation of exact optimal designs on convex polyhedra]. Industrial Laboratory. 45 (3). 249-251. [in Russian].

27.Lyashenko, T. V. (1981). Planirovanie eksperimenta po opisaniyu sistem s gruppami linejno svyazannyh vhodov [Design of experiment to describe systems with groups of linearly connected inputs]. In Organizaciya i Avtomatizaciya na Eksperimentalnite Izsledvaniya. 110-113. Ruse. Bulgaria: Ministerstvo na elektronikata i elektrotekhnikata. [in Russian].

28. Myers, R. M., Montgomery, D. C. (2002). Response Surface Methology: Process and Product Optimization Using Designed Experiment. $2^{\text {nd }}$ ed. John Wiley \& Sons.

29.Montgomery, D. C. Design and Analysis of Experiments, $10^{\mathrm{th}} \mathrm{ed}$. John Wiley \& Sons.

30.Lyashenko, T., Voznesensky, V. (2007). Compromise optimisation of slag alkaline binders with computational materials science methods. In Alkali Activated Materials - Research, Production and Utilization. Proc. Int. Conf.. 447-458. Prague: CRA.

31.Lyashenko, T. V., Voznesensky, V. A., Gavriliuk, V. P. (2009) Multicriteria optimisation of autoclaved aerated concrete properties and expenditure of energy resources. In Brittle Matrix Composites. 9. 219-226. Cambridge: Woodhead Publ. Ltd., Warsaw: IFTR PAS. 
32. Lyashenko, T. V. (2015). Composition-process fields methodology for design of composites structure and properties. In Brittle Matrix Composites. 11. 289-298. Warsaw: IFTR PAS.

33.Lyashenko, T., Kryukovskaya, S. (2012). Modelling the influence of composition on rheological parameters and mechanical properties of fibre reinforced polymer-cement mortars. In Brittle Matrix Composites, 10, 169-178. Cambridge: Woodhead Publ. Ltd. Warsaw: IFTR.

\section{Література}

1. Mindes S. High performance concrete: where do we go from here? In A. M. Brandt, V. C. Li, I. H. Marshall (Eds.), Brittle Matrix Composites. Cambridge: Woodhead Publ. Ltd., Warsaw: ZTUREK RSI. 2006. №8. P. 15-23.

2. C. Shi and Y. L. Mo. High-Performance Construction Materials. Science and Applications World Scientific. 2008. 448 p. https://doi.org/10.1142/6793

3. W. P. De Wilde, C. A. Brebbia and S. Hernández. High Performance Structures and Materials VI. WITpress. 2012. $558 \mathrm{p}$.

4. Constable G., Somerville B. A Century of Innovation: Twenty Engineering Achievements that Transformed our Lives. Washington, DC: Joseph Henry Press. 2003.256 p. https://doi.org/10.17226/10726

5. Caijun Shi C., Roy, D., Krivenko, P. Alkali-Activated Cements and Concretes. CRC Press. 2019. $392 \mathrm{p}$.

6. P. Samui, D. Kim, N. Iyer, S. Chaudhary (Eds.). New Materials in Civil Engineering, ButterworthHeinemann. 2020. 1104 p.

7. Khan M., Cao M. Effect of hybrid basalt fibre length and content on properties of cementitious composites. Magazine of Concrete Research. 2021. 73 (10). P. 487-498. https://doi.org/10.1680/jmacr.19.00226

8. Вознесенский В. А., Ляшенко Т. В., Иванов Я. П., Николов И. И. ЭВМ и оптимизация композиционных материалов. Киев: Будівельник, 1989. 240 с.

9. Ляшенко Т. В., Вознесенский В. А. Методология рецептурно-технологических полей в компьютерном строительном материаловедении. Одесса: Астропринт, 2017. 168 с.

10. Bentz D. P. Modelling cement microstructure: Pixels, particles, and property prediction. Materials and Structures. (1999). №32. P. 187-195.

11.Le N.L.B., Stroeven M., Sluys L. J., Stroeven P. A novel numerical multi-component model for simulating hydration of cement. Computational Materials Science. 2013. 78. 12-21.

12.Stroeven P., Slowik M. Economic and reliable estimation of cementitious material properties on the basis of virtual models. In M.A. Glinicki, D. Jóźwiak-Niedźwiedzka, C. K.Y. Leung, J. Olek (Eds.), Warsaw: Institute of Fundamental Technological Research. 2019. Brittle Matrix Composites 8. 35-44 pp.

13.Wittmann F. H., Roelfstra P. E., Sadouki H. Simulation and Analysis of Composite Structures. Materials Science and Engineering. 1984. 68. 239-248.

14.Garboczi E. J. The computational materials science of concrete: Past, present and future. American Ceramic Society Bulletin. 2013. 92 (4). 40-45.

15.Garboczi E. J., Bentz D. P. Computer simulation of the diffusivity of cement-based materials. J. of Materials Science. 1992. 27. 2083-2092.

16. Вознесенский В. А., Выровой В. Н., Керш В. Я., Ляшенко Т. В., и др. Современные методы оптимизации композиционных материалов Киев: Будівельник, 1983. 144 с.

17.Lyashenko T. V., Voznesensky, V. A. Experimental-statistical modeling in computational materials science. In: Proc. 3rd Int. Applied Statistics in Industry Conf. 1995. 287-298. Dallas: ACG Press.

18.Bunge M. A general black-box theory. Philosophy of Science. 1963. 30 (4). 346-358.

19. Ashby W. R. The black box. In An Introduction to Cybernetics. London: Chapman \& Hall. 1956. 86-117 pp.

20. Налимов В. В., Голикова Т. И. Логические основания планирования эксперимента. Издание 2-е, переработанное и дополненное. Москва: Металлургия, 1981. 152.

21. Вознесенский В. А. Статистические методы планирования эксперимента в техникоэкономических исследованиях. М.: Финансы и статистика, 1981. 263 с.

22.Sheffe H. Experiments with mixtures. J. Roy. Statist. Soc., B. 1958. 20 (2). 344-360. 
23. Sheffe H. Simplex-centroid design for experiments with mixtures. J. Roy. Statist. Soc., B. 1963. 25(2). 235-263.

24. Зедгинидзе И. Г. Планирование эксперимента для исследования многокомпонентных систем. М.: Наука, 1976. 390 с.

25. Vuchkov I. Jonchev H. Design and analysis of the experiment in studies of the properties of mixtures and alloys. Sofia: Tekhnika. 1979. 356.

26. Cornell J. A. Experiments with Mixtures: Designs, Models, and the Analysis of Mixture Data, 3rd ed. Wiley. 2002. 680.

27. Даниленко Е.Л., Ляшенко Т. В. Расчет точных оптимальных планов на выпуклых многогранниках. Industrial Laboratory, 1979. 45 (3). 249-251.

28. Ляшенко Т. В. (1981). Планирование эксперимента для описания систем с группами линейно связанных входов. Организация и автоматизация на эксперименталните. Русе. Болгария, 1981. с.110-113.

29. Myers R. M., Montgomery D. C. Response Surface Methology: Process and Product Optimization Using Designed Experiment, 2nd ed. John Wiley \& Sons. 2002. 814.

30.Montgomery D. C. Design and Analysis of Experiments, 10th ed. John Wiley \& Sons, 688.

31.Lyashenko T., Voznesensky V. (2007). Compromise optimisation of slag alkaline binders with computational materials science methods. In Alkali Activated Materials - Research, Production and Utilization. Proc. Int. Conf. Prague: CRA. 2007. 447-458 pp.

32.Lyashenko T. V., Voznesensky V. A., Gavriliuk V. P. (2009) Multicriteria optimisation of autoclaved aerated concrete properties and expenditure of energy resources. Cambridge: Woodhead Publ. Ltd., Warsaw: IFTR PAS. In Brittle Matrix Composites. 2009. 9. 219-226 pp.

33.Lyashenko T. V. Composition-process fields methodology for design of composites structure and properties. Warsaw: IFTR PAS. In Brittle Matrix Composites. 2016. 11. 289-298 pp.

34.Lyashenko T., Kryukovskaya S. Modelling the influence of composition on rheological parameters and mechanical properties of fibre reinforced polymer-cement mortars. Cambridge: Woodhead Publ. Ltd., Warsaw: IFTR. In Brittle Matrix Composites. 2012. 10. 169-178 pp.

\section{Tatiana Lyashenko}

Odessa State Academy of Civil Engineering and Architecture

Doctor of Technical Science, professor

Didrihsona str., 4, Odessa, Ukraine 65029

frabul16@gmail.com

ORCID: 0000-0002-6232-4866

\section{For references:}

Lyashenko T. (2021). Structured systems of factors and experimental-statistical models in studies of building composites. Mechanics and Mathematical Methods. 3 (1). $47-61$

\section{Для посилань:}

Ляшенко Т. В. Структуровані системи факторів і експериментально-статистичні моделі при дослідженні будівельних композитів. Механіка та математичні методи, 2021. Т. 3. №. 1. С. 47-61. 